ThufuLA: Jurnal Inovasi Pendidikan Guru Raudhatul Athfal

Volume 9 issue 1, 2021

DOI: $10.21043 /$ thufula.v9i1.10329

\title{
Pengembangan Website Penilaian Kinerja Guru Pendidikan Anak Usia Dini
}

\author{
Isnaini Kusuma Wardani
}

Universitas Kristen Satya Wacana Salatiga, Salatiga, Indonesia

942019008@student.uksw.edu

\section{Bambang Ismanto}

Universitas Kristen Satya Wacana Salatiga, Salatiga, Indonesia bambang.ismanto@uksw.edu

\section{Bambang S. Sulasmono}

Universitas Kristen Satya Wacana Salatiga, Salatiga, Indonesia sulasmonobambang@yahoo.com

Abstract: Developing Teacher Performance Appraisal Website of Early Childhood Education in IGABA Salatiga. The implementation of website in teacher performance appraisal ( $P K G$ ) is carried out to increase objectivity, validity, reliability, efficiency and effectiveness of human resource management. The purpose of this study was to develop a website application for the performance appraisal of Early Childhood Education (PAUD) teachers at Aisyiyah Bustanul Athfal Teacher Association (IGABA) Salatiga. This study uses the Research and Development method with the Sugiyono's research and development model, which includes seven research steps, namely potentials and problems, data collection, product design, design validation, design revision, product testing, product revision. As for a product development model, it uses the System Development Life Cycle Waterfall Model. To collect the data, the researchers used interviews, document study, and questionnaires. The researchers employed qualitative descriptive analysis in analyzing the data, and data triangulation to check the validation of the data. The results of this research were in the form of a website-based PKG PAUD application. Based on the results of expert validation, the websitebased PKG PAUD application is feasible to use. 
Furthermore, based on the questionnaire results of product trials in the field by five IGABA PAUD school principals, the product got a score of 4.6 which means that the product is very good and useful. It is proved to increase the effectiveness of the principal's performance in implementing $P K G$.

Keywords: PAUD teacher performance appraisal; website; development

Abstrak: Penerapan website dalam penilaian kinerja guru dilakukan untuk meningkatkan obyektivitas, validitas, realibilitas, efisiensi dan efektivitas manajemen sumber daya manusia. Tujuan dari penelitian ini adalah menyusun aplikasi website penilaian kinerja guru Pendidikan Anak Usia Dini di PAUD IGABA (Ikatan Guru Aisyiyah Bustanul Athfal) Salatiga. Penelitian ini menggunakan metode pengembangan Research and Development dengan model penelitian pengembangan Sugiyono, meliputi tujuh langkah penelitian, yaitu potensi dan masalah, pengumpulan data, desain produk, validasi desain, revisi desain, uji coba produk, revisi produk. Sebagai model pengembangan produk menggunakan System Development Life Cycle Waterfall Model. Metode pengumpulan data menggunakan wawancara, studi dokumen, dan kuesioner. Teknis analisis data menggunakan analisis deskriptif kualitatif, dan validasi data menggunakan triangulasi data. Hasil dari penelitian ini adalah berupa aplikasi PKG PAUD berbasis website dimana berdasarkan hasil validasi ahli, aplikasi PKG PAUD berbasis website ini layak digunakan. Sedangkan kuesioner hasil uji coba produk di lapangan oleh lima orang kepala sekolah PAUD IGABA, produk mendapatkan skor 4,6 yang berari bahwa produk tersebut sangat baik dan bermanfaat serta meningkatkat efektifitas kinerja kepala sekolah dalam pelaksanaan PKG.

Kata kunci: Penilaian kinerja guru PAUD; website; pengembangan

\section{A. Pendahuluan}

Dibutuhkan ilmu pengetahuan serta pengetahuan yang luas dan keahlian khusus dalam rangka lebih memaksimalkan kecerdasan anak. Untuk itu kedudukan Lembaga Pendidikan 
Anak Usia Dini (LPAUD) sangat berarti untuk mendidik anak supaya masa keemasan (Golden Age) tidak percuma. Data Badan Pusat Statistik tahun 2018, pemerintah bekerjasama dengan masyarakat berhasil meningkatkan angka partisipasi PAUD mulai periode 2011-2016, dari capaian pada tahun 2011 sebesar $24,50 \%$ menjadi $34,62 \%$ pada tahun 2016 atau naik pada angka 10,12\% (Mumpuni \& Ismanto, 2019). Hal tersebut menunjukkan bahwa PAUD semakin berkembang dan dibutuhkan masyarakat, sehingga kebutuhan akan adanya guru PAUD yang bermutu semakin besar pada saat jumlah lembaga PAUD terus meningkat. Keberhasilan PAUD tidak terlepas dari peran guru, mengingat kiprahnya dalam pengasuhan, perawatan, pendidikan dan perlindungan anak dalam upayanya mengoptimalkan kecerdasan dan perkembangan anak usia dini (Mumpuni \& Ismanto, 2019). Dengan melihat pentingnya peran guru PAUD tersebut, maka diperlukan guru PAUD yang profesional.

Profesionalisme guru PAUD adalah sebagai ujung tombak dalam implementasi kurikulum di kelas karena dalam proses belajar mengajar guru PAUD mempunyai tugas untuk mendorong, membimbing, dan memberi fasilitas belajar bagi siswa untuk mencapai tujuan pembelajaran. Untuk itu pemerintah terus melakukan berbagai upaya demi meningkatkan kompetensi guru profesional, yaitu melalui uji kompetensi guru (UKG), penilaian kinerja guru (PKG) dan pengembangan keprofesian berkelanjutan (PKB). Hal tersebut senada dengan pendapat Mulyasa (2013: 30) yang menyatakan bahwa program sertifikasi, UKG dan PKG yang dilanjutkan dengan pengembangan keprofesian berkelanjutan (PKB) merupakan cara yang digunakan pemerintah untuk memotong mata rantai penyebab rendahnya mutu guru. Salah satu kebijakan pemerintah yang dipandang efektif dalam meningkatkan kompetensi guru profesional adalah dengan melaksanakan penilaian kinerja guru (PKG) yang menjamin terjadinya proses pembelajaran yang berkualitas di semua jenjang pendidikan. Pendekatan penilaian kinerja guru hendaknya mengindikasikan standar kerja yang terkait, mengukur kriteria dan memberikan umpan balik kepada pegawai dan departemen SDM (Mangkuprawiro, 2003).

Penerapan PKG dimaksudkan tidak untuk mempersulit guru, namun kebalikannya, PKG dilaksanakan supaya tercipta 
guru yang profesional, sebab harkat serta martabat sesuatu pekerjaan ditentukan oleh mutu layanan profesi yang berkualitas. Tidak hanya perihal itu evaluasi kemampuan pada guru juga untuk membuktikan secara tepat mengenai aktivitas guru di dalam pembelajaran, serta membantu guru dalam meningkatkan kompetensinya. Dengan begitu diharapkan guru bisa berkontribusi pada peningkatan mutu pembelajaran, serta membantu pengembangan karir guru dalam mencapai profesionalitas (Mulyasa, 2013). Penilaian Kinerja Guru memberikan jaminan bahwa guru dapat bekerja dan melaksanakan pekerjaannya secara profesional dan mampu memberikan layanan yang berkualitas terhadap masyarakat, khususnya peserta didik. Oleh karena itu, untuk meyakinkan bahwa setiap guru adalah seorang profesional di bidangnya, maka penilaian kinerja guru penting dilakukan terhadap guru di semua satuan pendidikan formal yang diselenggarakan oleh pemerintah, pemerintah daerah, dan masyarakat (Mulyasa, 2013). Mulyasa menambahkan bahwa penilaian kinerja guru juga memberikan jaminan bahwa guru dapat bekerja dan melaksanakan pekerjaannya secara profesional dan mampu memberikan layanan yang berkualitas terhadap masyarakat, khususnya peserta didik. Oleh karena itu, penilaian kinerja guru harus dilakukan pada semua guru di semua jenjang pendidikan formal, untuk meyakinkan bahwa setiap guru adalah seorang profesional di bidangnya.

Pentingnya pelaksanaan penilaian kinerja guru juga dinyatakan oleh Dewi dan Suryana dalam penelitiannya di PAUD Al Azhar Bukittinggi, membuktikan bahwa evaluasi kinerja pendidik PAUD dapat meningkatkan kemampuan guru dalam merencanakan dan melaksanakan pembelajaran serta membimbing dan melatih peserta didik (Dewi \& Suryana, 2020). Hal tersebut juga sejalan dengan penelitian Zahroh yang berjudul "Evaluasi Kinerja Guru Dalam Peningkatan Mutu Pendidikan di Yayasan Al Kenaniyah Jakarta Timur" membuktikan bahwa evaluasi kinerja guru dilaksanakn menyangkut dalam perencanaan pembelajaran, pelaksanaan pembelajaran, penilaian hasil belajar, juga disiplin guru dalam melaksanakan tugas, mampu menghasilkan guru yang mempunyai kinerja baik, sehingga mutu pendidikan yang ada akan bernilai baik (Zahroh, 2017). Menurut Ministry of National Education, 2006, menyatakan bahwa "the performance 
assessment is a way of giving feedback to the employees by evaluating their performance through the predetermined criteria. The fact that teachers receive feedback about their teaching performance in a longer period compared to other professions reveals the need for a different method of evaluation (Peterson, 1995). Hal tersebut dimaksudkan bahwa penilaian kinerja guru merupakan cara untuk memberikan umpan balik kepada guru dengan mengevaluasi kinerjanya melalui kriteria yang telah ditentukan. Namun pada kenyataan di lapangan, pelaksanaan PKG seringkali menemui kendala, seperti yang dinyatakan Darsinah dalam penelitiannya yang berjudul Pengembangan Instrumen Penilaian Kinerja Guru TK, menyatakan bahwa untuk mengoptimalkan kinerja guru TK di kota Surakarta perlu dilakukan penilaian kinerja guru dengan menggunakan Instrumen Penilaian Kinerja Guru TK (IPKGTK). Sementara itu, pada prakteknya, pelaksanaan penilaian kinerja guru TK di kota Surakarta masih menggunakan Instrumen Penilaian Kinerja Guru Sekolah, sehingga mengakibatkan kinerja guru TK belum maksimal (Darsinah, 2012).

Permasalahan dalam pelaksanaan PKG juga dinyatakan oleh Erwandi, dkk dalam penelitiannya yang berjudul "Sistem Pendukung Keputusan Untuk Penilaian Kinerja Guru Menggunakan Metode Weight Product" membuktikan bahwa pada Madrasah Ibtidaiyah Condong penilaian kinerja dilakukan terhadap beberapa guru dengan proses pengolahan data. Penilaian kinerja guru masih semi-terstruktur sehingga membutuhkan waktu, cenderung terjadinya input data secara berulang serta kesalahan dalam input data, penyimpanan data yang kurang efisien mengakibatkan proses pencarian data menjadi lebih lama sehingga pihak sekolah kesulitan dalam menentukan prestasi serta mengevaluasi kinerja guru secara keseluruhan (Erwandi et al., 2018). Kendala dalam pelaksanaan PKG di PAUD juga terjadi di lingkungan PAUD IGABA Salatiga. IGABA (Ikatan Guru 'Aisyiyah Bustanul Athfal) adalah lembaga PAUD dibawah naungan Yayasan 'Aisyiyah/Muhamadiyah Salatiga. Berdasarkan hasil studi awal penelitian melalui wawancara, observasi dan kuesioner yang dilakukan peneliti kepada subyek penelitian pada bulan Juli 2020, saat ini pelaksanaan penilaian kinerja guru PAUD IGABA masih menggunakan sistem penilaian manual/konvensional yaitu masih dengan pengisian tertulis lembar format dokumen 
penilaian. Hal tersebut menyebabkan proses evaluasi kinerja tergolong relatif lama dan sulit pelaksanaannya. Data manual yang dihasilkan juga sulit digunakan untuk proses berkelanjutan yang berhubungan dengan evaluasi kinerja guru karena akan menyita waktu yang lama jika harus mencari satu per satu data tersebut. Dengan adanya fenomena yang ditemukan, maka peneliti tertarik untuk melakukan penelitian di PAUD IGABA dan berusaha mengupayakan solusi untuk mengatasi berbagai permasalahan yang dihadapi guru dan kepala sekolah dalam pelaksanaan penilaian kinerja guru. Sebagai solusinya, peneliti merancang bangun suatu produk baru, yaitu aplikasi penilaian kinerja guru berbasis website.

Senada dalam penelitian Wardatul Jannah dkk tentang "Rancang Bangun Sistem Informasi Bimbingan Belajar berbasis WEB (Studi Kasus Lembaga Bimbingan Belajar TADICA) membuktikan bahwa perancang sistem pembelajaran dari Lembaga Bimbingan Belajar TADICA yang dapat diakses melalui internet dan dikelola oleh administrator sehingga pembelajaran menjadi cepat, tepat dan akurat (Jannah et al., 2016). Selanjutnya, peneliti akan melakukan penelitian dengan menggunakan metode Research and Development dengan mengembangkan model penelitian dan pengembangan Sugiyono (Sugiyono, 2015). Peneliti memilih model pengembangan tersebut karena langkah-langkah dalam tahapan tersebut tepat bila digunakan untuk menciptakan produk baru yang kreatif, original dan teruji. Menciptakan produk baru yang kreatif berarti membuat produk baru yang memiliki nilai tambah dan belum pernah ada. Sedangkan untuk pengembangan produk baru tersebut, peneliti menggunakan model pengembangan System Development Life Cycle (SDLC) Waterfall (Pressman, 2010). Model ini dipilih karena ini adalah model klasik yang bersifat sistematis dan berurutan dalam membangun suatu software. Berdasarkan latar belakang masalah diatas, maka dapat dibuat rumusan masalah sebagai berikut: Pertama, Bagaimana pelaksanaan Penilaian Kinerja Guru yang dilakukan oleh Kepala Sekolah PAUD IGABA Salatiga saat ini?; Kedua, Apa kelebihan dan kekurangan pelaksanaan Penilaian Kinerja Guru yang dilakukan oleh Kepala Sekolah PAUD IGABA Salatiga saat ini?; Ketiga, PKG PAUD yang bagaimana yang dapat dikembangkan guna mempermudah dan 
memperingan tugas Kepala Sekolah PAUD IGABA dalam melksanakan PKG?

\section{B. Pembahasan}

\section{Potensi dan Masalah}

Tahap ini adalah sebagai tahap awal untuk mengetahui potensi dan masalah yang ada, dimana pada studi pendahuluan melalui observasi dan wawancara pada subyek penelitian, peneliti mendapat informasi bahwa kepala sekolah PAUD IGABA secara kontinyu dan berkala melaksanakan PKG untuk meningkatkan kompetensi guru. Namun pada prakteknya, pelaksanaan PKG di PAUD IGABA yang masih bersifat manual/konvensional menimbulkan berbagai kendala, yaitu: a). Lembar dokumen instrumen PKG yang harus dipersiapkan cukup banyak dan merepotkan; b). Diperlukan biaya yang relatif besar untuk mencetak dokumen instrumen PKG; c). Pada saat dokumen dikumpulkan ke bagian administrasi, dokumen sering rusak atau tertukar; d). Adanya kemungkinan terjadi kesalahan pada saat rekapitulasi penilaian.

\section{Pengumpulan data}

Dari potensi dan masalah yang didapat, peneliti mengumpulkan informasi dengan tehnik wawancara terstruktur dan kuesioner yang diberikan kepada kepala sekolah dan guru. Dari hasil pengumpulan data, peneliti mendapati bahwa pelaksanaan PKG di Paud IGABA masih dilakukan secara manual/konvensional sehingga menyebabkan pelaksanaan PKG belum maksimal. Untuk mengatasi kendala tersebut, peneliti membuat suatu produk, yaitu aplikasi PKG berbasis website dengan tujuan bahwa produk tersebut dapat meningkatkan efektifitas kinerja kepala sekolah dalam pelaksanaan PKG.

Hal itu dengan pemikiran Rezky B. J Purba, dkk dalam penelitiannya yang berjudul Rancang Bangun Penilaian Kinerja Guru Berbasis Aplikasi Web membuktikan bahwa dengan adanya sistem penilaian kinerja guru yang awalnya memakan waktu lama dan ada kendala dalam penyimpanan data, maka setelah dilaksanakan PKG berbasis web ini, PKG dapat dilakukan secara cepat dan data yang ada disimpan langsung ke dalam sebuah basis data sehingga dapat ditampilkan dan digunakan 
disaat yang diperlukan (Purba et al., 2013). Penelitian tersebut senada dengan hasil dari penelitian yang dilakukan oleh peneliti yang membuktikan bahwa produk berupa aplikasi PKG PAUD IGABA berbasis website mempermudah kepala sekolah dalam penilaian PKG, rekapitulasi skor, penyimpanan file hasil penilaian dan memudahkan dalam pencarian kembali history file PKG.

\section{Desain Produk}

Pada tahap ini dikembangkan desain/rancangan produk pengembangan website penilaian kinerja guru. Peneliti bersama dengan programmer merancang pemodelan arsitektur system, struktur data, arsitektur software dan tampilan interface produk. Rancangan aplikasi dibangun dengan platform web, agar lebih mudah untuk diakses. Aplikasi ini memiliki dua tampilan, yaitu aplikasi untuk guru dan aplikasi untuk kepala sekolah dengan menu-menu sebagai berikut:

a. Aplikasi Kepala Sekolah

Kepala Sekolah dapat login pada akun kepala sekolah tersebut dengan memasukkan username dan password seperti tampak pada gambar berikut:

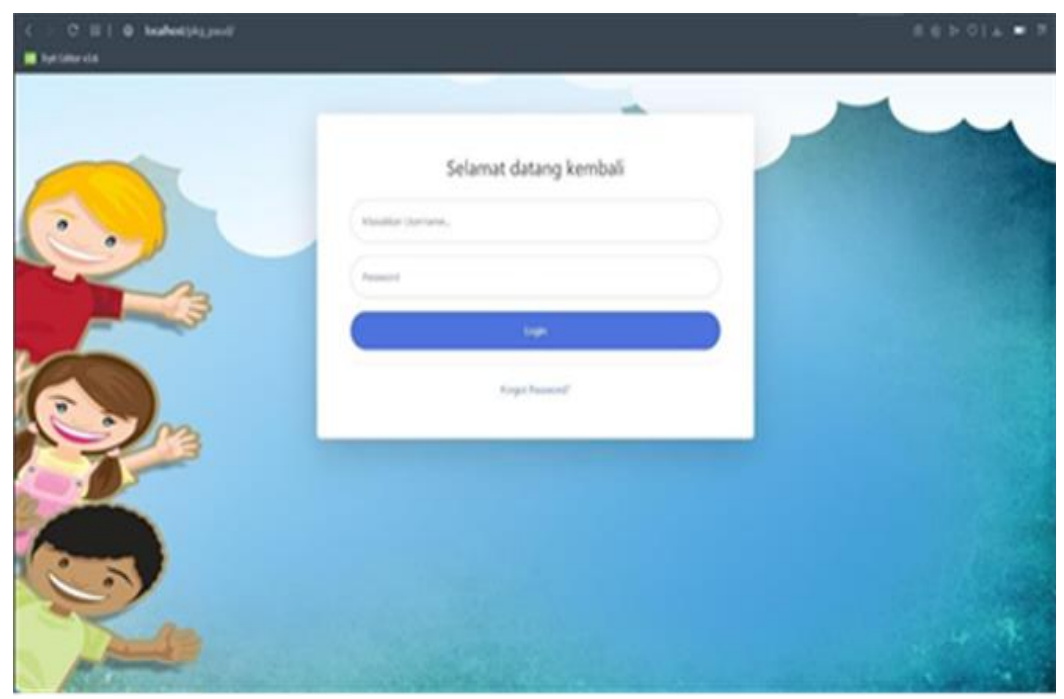

Gambar 1. Tampilan halaman login 
Setelah mengisi username dan password kepala sekolah bisa masuk ke halaman Dashboard Kepala Sekolah yang berisi Profil Pribadi, Data Guru, Data Sekolah, Dokumen Pendukung PKG dan Penilaian seperti tampak ada gambar berikut:

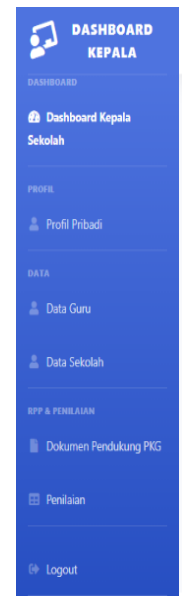

Gambar 2. Tampilan halaman Dashboard Kepala Sekolah

Selanjutnya pada halaman Penilaian memuat instrumen PKG PAUD yang mengacu pada (Peraturan Menteri Pendayagunaan Aparatur Negara Dan Reformasi Birokrasi RI Nomor 16, Tahun 2009, Tentang Standar Kualifikasi Akademik Dan Kompetensi Guru, 2009) dan juga PKG PAUD IGABA yang mengacu pada Majelis Pendidikan Dasar dan Menengah Yayasan Aisyiyah Salatiga . 
166 | Isnaini Kusuma Wardani, et.al.

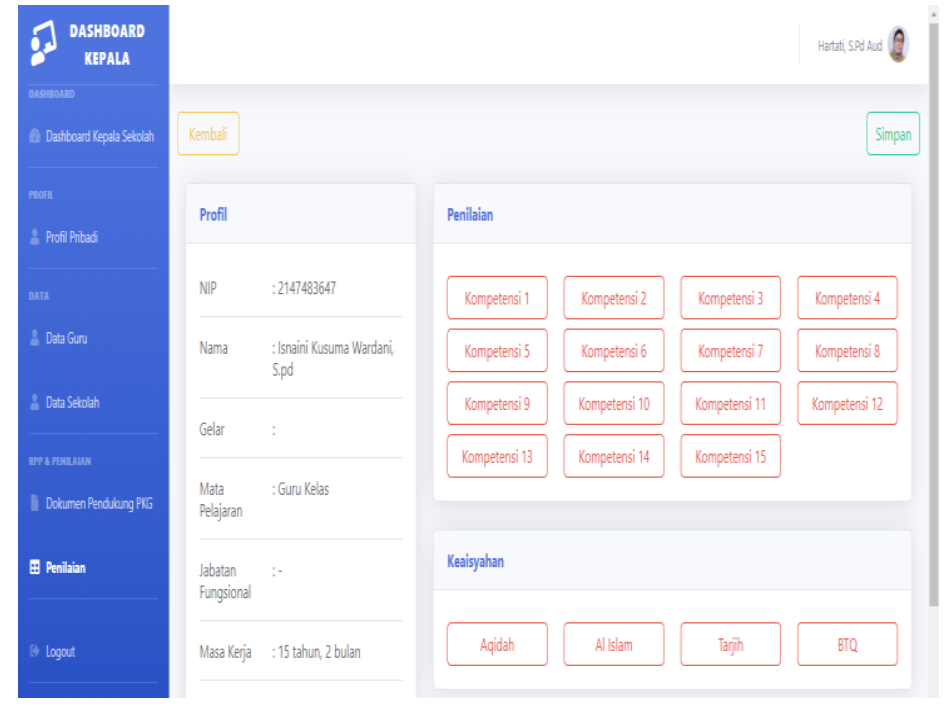

Gambar 3. Tampilan halaman Penilaian

b. Aplikasi Guru

Guru dapat login pada akun guru tersebut dengan memasukkan username dan password yang di miliki masingmasing guru seperti tampak pada gambar berikut:

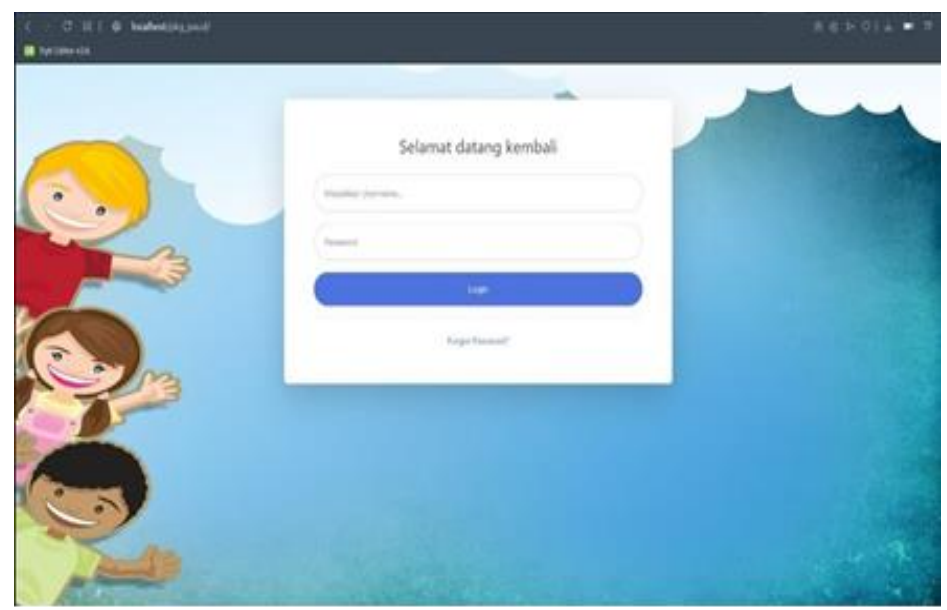

Gambar 4. Tampilan halaman login

Selanjutnya pada halaman Dashboard Guru berisi sub-sub menu, yaitu Profil Pribadi, RPP, Penilaian dan Logout, seperti pada gambar berikut: 
$\cong \quad$ ThufuLA: Jurnal Inovasi Pendidikan Guru Raudhatul Athfal | 167

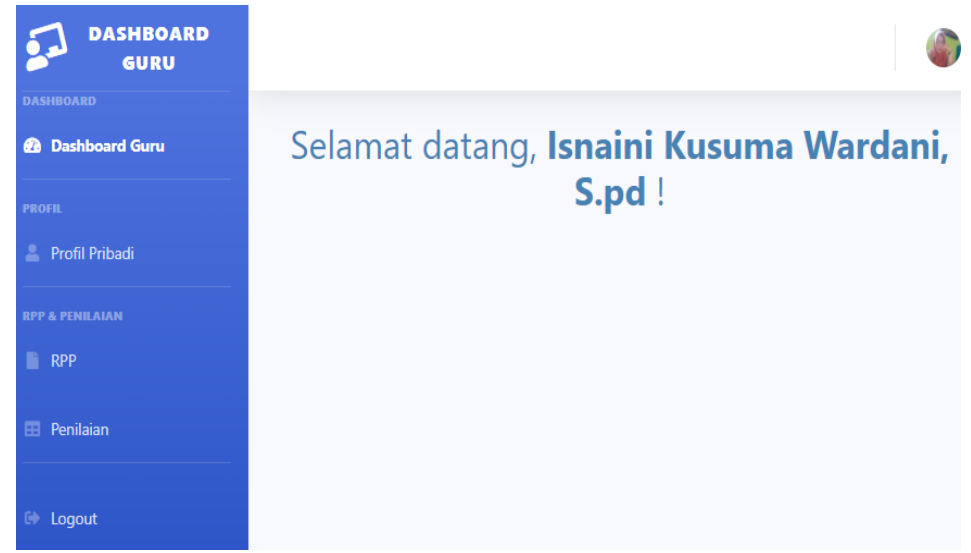

Gambar 5. Tampilan halaman Dashboard Guru

Pada halaman Upload RPP, guru dapat mengunggah file pendukung PKG.

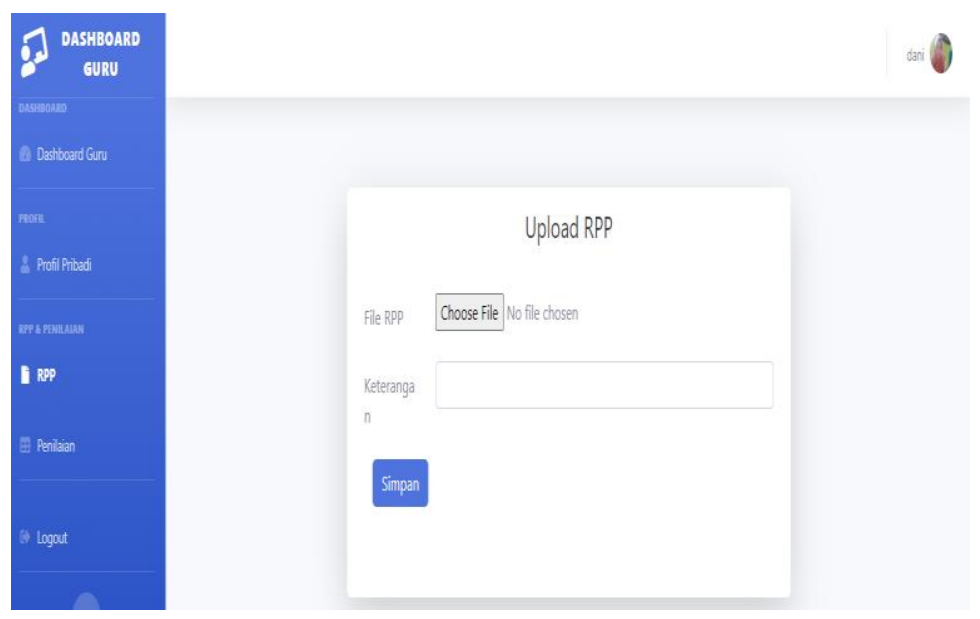

Gambar 6. Tampilan halaman Upload RPP

Selanjutnya pada halaman Penilaian guru dapat melihat skor yang diproleh. 
168 | Isnaini Kusuma Wardani, et.al.

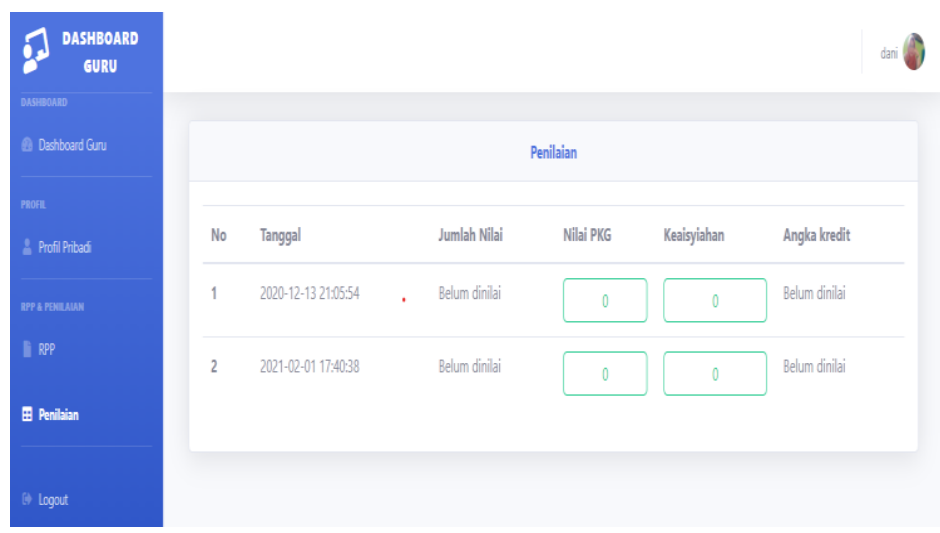

Gambar 7. Tampilan halaman penilaian

\section{Validasi Produk}

Untuk meningkatkan kepercayaan terhadap hasil penelitian dan pengembangan, maka perlu dilakukan pengujian validitas terhadap produk supaya diketahui tentang kemanfaatan produk, kelemahan dan kekuatan produk tersebut. Validasi dilakukan oleh ahli IT yang menguji desain produk dan ahli PAUD yang menguji instrumen PKG PAUD . Sedangkan tehnik validasi data menggunakan triangulasi, baik itu triangulasi sumber, maupun triangulasi tehnik. Hasil dari validasi website dapat dilihat pada tabel dibawah ini:

Tabel 1. Hasil Uji Validasi Ahli IT

\begin{tabular}{|c|c|c|c|c|c|c|}
\hline \multirow[t]{2}{*}{ No } & \multirow{2}{*}{ Pertanyaan } & \multicolumn{5}{|c|}{ Jawaban } \\
\hline & & SS & $\mathrm{S}$ & KS & TS & STS \\
\hline 1 & $\begin{array}{l}\text { Layout website rapi serta enak } \\
\text { dilihat }\end{array}$ & & $\sqrt{ }$ & & & \\
\hline 2 & $\begin{array}{l}\text { Absen script compatible pada } \\
\text { website }\end{array}$ & & $\sqrt{ }$ & & & \\
\hline 3 & $\begin{array}{l}\text { Website ini compatible untuk } \\
\text { semua jenis browser }\end{array}$ & & $\sqrt{ }$ & & & \\
\hline 4 & $\begin{array}{l}\text { Dalam mengakses website } \\
\text { memiliki loading yang cepat }\end{array}$ & & $\sqrt{ }$ & & & \\
\hline 5 & $\begin{array}{l}\text { Konten website berkualitas dan } \\
\text { mudah dibaca }\end{array}$ & & $\sqrt{ }$ & & & \\
\hline 6 & Warna website menarik & & $\sqrt{ }$ & & & \\
\hline 7 & Font yang digunakan sesuai & & $\sqrt{ }$ & & & \\
\hline 8 & $\begin{array}{l}\text { Mencakup } 15 \text { kompetensi PKG } \\
\text { PAUD }\end{array}$ & $\sqrt{ }$ & & & & \\
\hline
\end{tabular}




\begin{tabular}{lll}
9 & $\begin{array}{l}\text { Mengintegrasikan kompetensi } \\
\text { PKG Keaisyiyahan }\end{array}$ & \\
\hline 10 & $\begin{array}{l}\text { Inputing dokumen pendukung } \\
\text { PKG mudah }\end{array}$ & $\sqrt{ }$ \\
\hline 11 & Kejelasan halaman website & $\sqrt{ }$ \\
\hline 12 & Kemudahan proses penilaian & $\sqrt{ }$ \\
\hline 13 & Kemudahan mengunduh hasil & $\sqrt{ }$ \\
& penilaian & \\
\hline 14 & $\begin{array}{l}\text { Sistematika perhitungan skor } \\
\text { PKG }\end{array}$ & $\sqrt{ }$ \\
\hline 15 & $\begin{array}{l}\text { Website ini mudah untuk } \\
\text { pengembangan berkelanjutan }\end{array}$ & \\
\hline & $\begin{array}{l}\text { SS : Sangat Setuju } \\
\text { S : Setuju } \\
\text { KS : Kurang Setuju } \\
\text { TS : Tidak Setuju } \\
\text { STS : Sangat Tidak Setuju }\end{array}$ \\
\end{tabular}

Dari tabel diatas dapat disimpulkan bahwa validator IT menyatakan Setuju (S) website layak digunakan karena layout website menarik, rapi, enak dilihat dengan tampilan yang jelas pada tiap halamannya dan website compatible untuk semua jenis browser dengan loading yang cepat. Selain itu website memuat PKG PAUD dan PKG Keaisyiyahan/Kemuhammadiyahan dengan kemudahan penilaian dan rekapitulasi penilaian yang sistematis. Sedangkan hasil validasi instrumen oleh ahli PAUD menyatakan bahwa instrumen PKG termuat dalam website lengkap karena memuat instrumen PKG PAUD yang mengacu pada Permen PAN dan RB No. 16 Tanun 2009 dan instrumen PKG Keasyiyahan/Kemuhammadiyahan bersumber dari rumusan majelis Dikdasmen Aisyiyah.

\section{Revisi Desain}

Setelah desain produk divalidasi melalui diskusi dengan pakar, maka diketahui kelemahannya. Selanjutnya peneliti mencoba melakukan perbaikan terhadap rancangan desain aplikasi PKG website tersebut untuk meminimalisir kelemahan dan kekurangan produk. Perbaikan tersebut berdasar pada masukan ahli IT dan juga ahli PAUD. Perbaikan dilakukan sesuai dengan saran dari validator ahli IT yaitu tersedianya manajemen organisasi file dalam website. Hal ini dimaksudkan 
bahwa dalam aplikasi website PKG Paud perlu ditambah login untuk user administrator. Tugas dari user admin adalah mengelola data, antara lain menginput data dan bertanggungjawab pada perubahn data, baik itu data pada akun guru maupun akun kepala sekolah.

\section{Uji Coba Produk}

Setelah rancangan produk dibuat menjadi produk, maka produk tersebut selanjutnya diuji efektifitas dan efisiensinya dengan pengujian eksternal. Ujicoba produk dilakukan kepada lima orang kepala sekolah PAUD IGABA Salatiga dimana kelima Lembaga tersebut dibawah Yayasan Aisyiyah Salatiga. Program kurikulum yang diterapkan di PAUD IGABA saat ini tidak hanya mengacu pada Permendikbud No. 146 Tahun 2014 tentang Kurikulum 2013 Pendidikan Anak Usia Dini, tetapi juga terintegrasi dengan Pendidikan Al-Islam serta Keasyiyahan/ Kemuhammadiyahan dan Pendidikan budaya atau pengembangan karakter bangsa sesuai dengan perkembangan anak. Untuk itu uji coba produk dilakukan pada kelima kepala sekolah PAUD IGABA karena instrumen PKG website ini tidak hanya memuat PKG PAUD secara umum tetapi juga instrumen PKG Keaisyiyahan/kemuhammadiyahan.

Uji coba dilakukan pada subyek penelitian pada tanggal 8, 10 dan 15 Desember 2020. Pada tahap uji coba produk, secara umum disimpulkan bahwa bahwa produk aplikasi PKG PAUD berbasis website ini sangat praktis, menarik dan efisien serta mempermudah tugas kepala sekolah dalam pelaksanaan PKG. Hal tersebut ditegaskan oleh pendapat kepala sekolah TK ABA 3 yang menyatakan bahwa website tersebut compatible untuk semua jenis browser dan memiliki loading yang cepat. Sejalan dengan pendapat tersebut, kepala sekolah TK ABA 5 juga menyatakan bahwa website memiliki desain yang menarik dan font yang sesuai. Sementara itu kepala sekolah TK ABA 1 berpendapat bahwa website mempermudah PKG.

Sebagai langkah awal peneliti menerangkan cara login dalam aplikasi, yaitu dengan mengisi username dan password. Setelah itu kepala sekolah bisa mulai dengan membuka profil pribadi, melihat data guru dan melakukan penilaian kinerja guru. Peneliti menjelaskan langkah-langkah pengisian 
instrumen PKG, yaitu dengan cara mengklik instrumen kompetensi PKG PAUD yang telah ada pada aplikasi. Ada 15 kompetensi PKG PAUD yang mengacu pada Permen PAN dan RB No. 16 Tahun 2009 dan 4 kompetensi PKG PAUD Keaisyiyahan. Setelah melakukan ujicoba produk, kepala sekolah mengisi angket yang sudah disediakan oleh peneliti. Angket tersebut berisi indikator uji lapangan, yang meminta pendapat responden tentang aplikasi website tersebut. Hasil dari angket angket uji coba lapangan kelima subyek penelitian adalah sebagai berikut:

Tabel 2. Hasil Uji Coba Lapangan

\begin{tabular}{|c|c|c|c|}
\hline No & Indikator & Score & Kriteria \\
\hline 1 & Layout website rapi serta enak dilihat & 5 & SS \\
\hline 2 & Tidak ada absen script yang dirasa membebani website & 4 & S \\
\hline 3 & Website ini compatible untuk semua jenis browser & 4.4 & S \\
\hline 4 & Dalam mengakses website memiliki loading yang cepat & 4 & 5 \\
\hline 5 & Konten website berkualitas dan mudah dibaca & 4.8 & S \\
\hline 6 & Website mudah digunakan & 4.6 & 5 \\
\hline 7 & Desain website menarik & 4.8 & $S$ \\
\hline 8 & Font yang digunakan sesuai & 4.8 & $\mathrm{~S}$ \\
\hline 9 & Gambar yang digunakan dalam website sesuai & 4.8 & 5 \\
\hline 10 & Website ini mempermudah penilaian kineria guru & 4.8 & 5 \\
\hline 11 & $\begin{array}{l}\text { Penilaian kineria guru berbasis website bermanfaat } \\
\text { untuk pengembangan lembaga PAUD }\end{array}$ & 4.8 & S \\
\hline & Rata-rata & 4.6 & S \\
\hline \multicolumn{2}{|r|}{ Keterangan Kriteria: } & & \\
\hline & $5.00 \quad$ Sangat Setuju (SS) & & \\
\hline & $4.99-4.00$ & & \\
\hline & Kurang Setuju (KS) & & \\
\hline & Tidak Setuju (TS) & & \\
\hline & Sangat Tidak Setuju (STS) & & \\
\hline
\end{tabular}

Dari tabel 2. diketahui bahwa nilai rata-rata 4.6 terdapat pada interval 4.99 - 4.00 dalam kategori S (Setuju). Hal ini dapat diartikan bahwa menurut Kepala Sekolah TK Paud IGABA, aplikasi website PKG PAUD ini sangat praktis, menarik dan efisien serta mempermudah tugas kepala sekolah dalam pelaksanaan PKG.

\section{Revisi Produk}

Revisi produk dilakukan berdasarkan masukan dan saran dari Kepala Sekolah pada saat uji coba produk. Revisi pertama yaitu adanya penambahan menu pada database yaitu dengan 
menambahkan sub-sub menu pada Data dukung $P K G$, seperti sub menu Prota, Prosem, RPPM, RPPH dan Penilaian. Dengan demikian menu Data dukung PKG akan lebih tersruktur dan jelas sehingga lebih memudahkan Kepala Sekolah saat akan melihat file ketika melaksanakan penilaian kinerja guru. Revisi yang kedua yaitu adanya penambahan menu saran pada database sehingga dimungkinkan kepala sekolah bisa memberi masukan/saran saat melakukan penilaian kinerja terhadap guru dimana saran dari kepala sekolah tersebut dilakukan untuk perbaikan dan kemajuan dari guru yang dinilai. Setelah produk direvisi maka didapatkan sebuah produk yang benarbenar layak untuk digunakan. Aplikasi PKG PAUD berbasis website diharapkan dapat mengatasi berbagai kendala yang dihadapi kepala sekolah dalam pelaksanaan PKG, diantaranya adalah aplikasi website ramah lingkungan atau paperless karena sudah tidak menggunakan media kertas untuk instrumennya. Kepala sekolah tidak akan kesulitan ketika rekapitulasi skor karena telah terbantu oleh system. Disamping itu penyimpanan hasil penilaian sangat praktis, tidak mebutuhkan banyak tempat dan mudah dalam pencarian history PKG karena semua file telah rapi tersimpan dalam database. Namun, tiada gading yang tak retak, penelitian ini masih jauh dari sempurna. Dikarenakan keterbatasan peneliti maka penelitian menggunakan model pengembangan Sugiyono hanya dilakukan hanya sampai tahap tujuh/revisi produk sehingga uji coba produk hanya dilakukan satu kali saja dengan skala terbatas.

\section{Simpulan}

Penelitian ini menghasilkan beberapa kesimpulan. Pertama, pelaksanaan PKG di PAUD IGABA saat ini masih dilaksanakan secara konvensional/manual. Kedua, sistem pelaksanaan PKG yang manual ini memiliki kelebihan, yaitu sangat valid maksudnya dokumen-dokumen pendukung PKG disajikan secara otentik/nyata. Sedangkan kelemahan/kekurangan PKG manual adalah: a) Lembar dokumen instrumen PKG yang harus dipersiapkan cukup banyak dan merepotkan; b) Diperlukan biaya yang relatif besar untuk mencetak dokumen instrumen PKG; c) Ketika dokumen diserahkan pada bagian administrasi seringkali dokumen rusak atau tertukar; d) Adanya kemungkinan terjadi kesalahan pada saat rekapitulasi penilaian; e) Perlu ruang tersendiri untuk tempat penyimpanan 
dokumen hasil penilaian. Ketiga, aplikasi PKG yang dikembangkan untuk mengatasi kendala pelaksanaan PKG manual di PAUD IGABA adalah aplikasi PKG berbasis website. Dimana aplikasi ini praktis bisa diakses dimanapun oleh semua user dan paperless tidak membutuhkan lembar dokumen PKG karena instrumen PKG PAUD baik itu yang mengacu permen PAN dan RB No. 16 Tahun 2009 maupun instrumen PKG Keaisyiyahan/Kemuhammadiyahan semua sudah termuat dalam website. Kepala sekolah juga tidak akan kesulitan dalam rekapitulasi skor PKG karena by system. Tidak perlu tempat luas untuk penyimpaan hasil PKG karena semua file telah tersimpan dalam database sehingga memudahkan untuk pencarian kembali file. Dengan demikian aplikasi PKG berbasis website akan memudahkan dan meringankan tugas kepala sekolah dalam pelaksanan PKG.

\section{Referensi}

Darsinah, D. (2012). Pengembangan Model Instrumen Penilaian Kinerja Guru TK. Jurnal Penelitian Pendidikan Unnes, 29(1), 1-6. https://doi.org/10.15294/jpp.v29i1.5639

Dewi, I., \& Suryana, D. (2020). Analisis Evaluasi Kinerja Pendidik Pendidikan Anak Usia Dini di PAUD Al Azhar Bukittinggi. Jurnal Obsesi : Jurnal Pendidikan Anak Usia Dini, 4(2), 1051-1059. https://doi.org/10.31004/obsesi.v4i2.465

Erwandi, D., Mulyani, E. D. S., \& Senjaya, A. S. (2018). Sistem Pendukung Keputusan Untuk Penilaian Kinerja Guru Menggunakan Metode Weighted Product (Studi Kasus : Madrasah Ibtidaiyah Condong) | Erwandi | Konferensi Nasional Sistem Informasi (KNSI) 2018. Konferensi Nasional Sistem Informasi (KNSI) 2018, 870-876. http://jurnal.atmaluhur.ac.id/index.php/knsi2018/article/ view/463

Jannah, W., Astuti, I. F., \& Maharani, S. (2016). Rancang Bangun Sistem Informasi Bimbingan Belajar Berbasis Web (Studi Kasus: Lembaga Bimbingan Belajar Tadica). Informatika Mulawarman : Jurnal Ilmiah Ilmu Komputer, 10(1), 47-53. https://doi.org/10.30872/jim.v10i1.20

Mangkuprawiro, T. S. (2003). Manajemen Sumber Daya Manusia Strategik. Ghalia Indonesia. 
Peraturan Menteri Pendayagunaan Aparatur Negara dan Reformasi Birokrasi RI Nomor 16, Tahun 2009, tentang Standar Kualifikasi Akademik dan Kompetensi Guru, (2009).

Mulyasa, H. E. (2013). Uji kompetensi dan penilaian kinerja guru (Cet. 3). Remaja Rosda Karya.

Mumpuni, N. D., \& Ismanto, B. (2019). Model Manajemen Pembelajaran Online Pada Pendidikan dan Pelatihan Guru Pendamping Muda PAUD. Kelola: Jurnal Manajemen Pendidikan, 6(2), 206-213. https://doi.org/10.24246/j.jk.2019.v6.i2.p206-213

Pressman, R. S. (2010). Software engineering : a practitioner's approach. McGraw-Hill Education.

Purba, R. B. J., Mustika, A., \& Irawan, M. I. (2013). Rancang Bangun Sistem Penilaian Kinerja Guru Berbasis Aplikasi Web. Jurnal Sains Dan Seni Pomits, 2(1), 1-6.

Sugiyono, S. (2015). Metode Penelitian \& Pengembangan Research and Development. Alfabeta.

Zahroh, M. N. (2017). Evaluasi Kinerja Guru Dalam Peningkatan Mutu Pendidikan Di Yayasan Al Kenaniyah Jakarta Timur. Jurnal Manajemen Pendidikan, 8(2), 139-149. https://doi.org/10.46244/visipena.v8i2.403 